\title{
Heritage advantages vs. economic constraints in the sustainable development framing: A study on social perception in Apuseni Mountains Natural Park
}

\author{
Gabriela Manea*1, Laura Maria Orbu', Elena Matei ${ }^{1}$, Mihaela Preda ${ }^{1}$, \\ Iuliana Vijulie', Roxana Guculici'1, Octavian Cocoș ${ }^{1}$, Alexandra Zaharia ${ }^{1}$ \\ 1 University of Bucharest, Romania
}

In a natural park, tourism is seen as an economic activity that can easily bring many benefits. Apuseni Natural Park (ANP)was chosen as a case study because it impacts communities (and especially moți) which have preserved their culture and traditions, coming from ancient times, in an area with remarkable natural and anthropogenic tourist resources. The aim of the study is to analyse the perception of local communities (endogenous), and visitors (exogenous), in order to highlight the heritage, economic advantages, and constraints in the natural park. The research is based on survey method and a number of spatial analysis tools, GIS, bibliographic sources, cartographic data mining, and field observations. The results show that local communities perceive in a high ratio the advantages of heritage preservation, linking them to the improvement of their life and less the disadvantages on the local economy. A more significant contrast in perception is revealed by tourists, who think that a national park has many advantages and constraints, the last ones accounting for the possible loss of functioning of the destination. In the frame of the recognised attractiveness of the ANP, the study suggests the need for a continuous monitoring process and the adoption of a receptive administration for each area and every actor involved.

Key Words: Apuseni Mountains Natural Park, moți, communities, heritage, tourists, perception, advantages, constraints.

Article Info: Received: August 21, 2019; Revised: September 30, 2019; Accepted: November 7, 2019; Online: November 30, 2019.

\section{${ }^{*}$ Corresponding author}

Address: Faculty of Geography, University of Bucharest, Blvd. Nicolae Bălcescu, no. 1, 010041 , Bucharest, Romania

Phone: +40213053813 | Email: maneagabriela2002@yahoo.com

(C)2019 Human Geographies; The authors 


\section{Introduction}

Protected areas cover about $25 \%$ of Romania's territory. According to the National Geographic site1, the country presently holds 1,000 natural protected areas, half of which are lacking administration. The purpose of Category V IUCN protected areas - Natural Parks - is to protect the values created by people's interaction with the landscape through traditional managerial practices. The creation of a natural park directly impacts the human communities, because this process is meant to increase their economic development and to enhance the visibility of their culture by getting them involved in the natural parks management, as well as in the capitalization of natural and cultural heritage, through the creation of new products and services (United Nations Conference, 1972; Brundtland Commission, 1983; Brundtland Report, 1987; United Nations Conference, 1992; World Summit on Sustainable Development, 2002, Abrudan \& Turnock, 1998).

Sustainable development, as a concept, focuses on balancing the three dimensions: economic, environmental, and social (Angelevska-Najdeska \& Rakicevik, 2012). In such a territorial category, with a management team of its own, it can be added the fourth dimension, respectively the institutional one (Foris, 2014; Matei, 2016). That is why it may be assumed that these protected areas could reach easier the targets of sustainable development than other regions or places. However, sustainability is difficult to establish and maintain. The researches considered as outposts of the application of this concept have focused on numerous and different aspects. Some of them related to the involvement of all actors in such an endeavour, having equally duties and benefits in the spirit of the principle of fairness (Wu et al., 2016; Hardy \& Pearson, 2017), either from top-down or vice-versa (Lyon et al., 2017) or by integrated approaches (Budeanu et al., 2016). Others are targeted on the idea of calculating sustainability through a series of indicators, by domain, simple or aggregated (Matei et al., 2011). In order to evaluate more accurately the degree of sustainability, it is necessary to take into account the perception of tourists (Almeida-García et al., 2016), residents (Ap, 1992) or stakeholders (D’ Mello et al., 2016; Domínguez-Gómez et al., 2017). In this context, the study aimed to highlight the heritage advantages and economic constraints that the natural park exerts on the local communities, within and in the vicinity of the protected area.

The study had the following objectives: 1. to explore the tourist resources and activities in the Apuseni Natural Park; 2. to evaluate the endogenous/exogenous perception about the natural park status and its impact on the local communities; 3. to formulate solutions for diminishing the constraints and for increasing the benefits for the local communities.

\section{Research methods and data management}

The study used the survey method and GIS analysis. To complete the research of mining bibliographic data, field observations were added. In order to study 
perception, the survey has employed the semi-structured interview tool. The sample consisted of 100 respondents, 50 locals (25 males and 25 females) and 50 tourists (25 males and 25 females). All subjects were Romanians by nationality, but their socio-professional structure was different: commercial workers, engineers, police officers, guesthouse owners, and guesthouse administrators. The sample of local communities belongs to the southern and central parts of the park, more exactly the Padiș area, and the settlements in the Arieșului Mare valley (Albac, Gârda de Sus, Arieșeni, and Scărișoara). The respondents in the second sample are tourists from different regions of the country. Concerning these groups (in situ and ex situ), composed of locals and tourists respectively, the authors have explored their perception regarding the traditions, heritage advantages and economic constraints that the natural park exerts on the local communities. The content was made via Google forms 19 to be applied in the field. Field research was carried out in two stages: the summer of 2017, when the focus was set on the analysis of the specific features of the human communities in the Apuseni Mountains, and the year 2018, when the authors went along the Arieșul Mic Valley, in order to observe Easter customs and traditions. The respondents ticked on a scale from 1 to 5 the degree of importance of the advantages and constraints of the natural park status.

The data collected has been processed in Excel 2010, Microsoft Office. Cartographic representations were made in ArcGIS 10 3.1, using CLC 2018. Several tools of ArcGIS 10.3.1 software were also applied: spatial analyst-point density for several tourist data, line density in case of accessibility, followed by raster reclassifications and map algebra.

\section{The study area frame and features}

The Apuseni Natural Park, located in the western part of Romania, includes territories lying in three counties, Bihor, Alba and Cluj, overlapping with the highest part of the Western Carpathians, respectively the Bihor Mountains, $(1,849 \mathrm{~m})$, and the Vlădeasa Massif (Figure 1). It is a remarkable area, which exhibits a diversity of natural and human resources, which increases its attractiveness. The natural attractions developed on karst topography contribute to the beauty of the landscape, which boasts several national records (Table 1).

The Human attractions of this park are tied to the communities living in its central and southern parts, especially those in the Padiș area and along the Arieșul Mare valley (Albac, Gârda de Sus, Arieșeni, Scărișoara), but also those situated beyond the park boundaries, in the Țara Moților region (Baia de Arieș, Bistra, Câmpeni, Vadu Moților). In fact, considering the millennial habitation of this natural park, which has played a key role in landscape shaping, the Apuseni Natural Park arouses a particular interest, not only from the point of view of the local communities within it, but also because it preserves many traditions, as well as the cultural identity in general (Photos 1-3). 


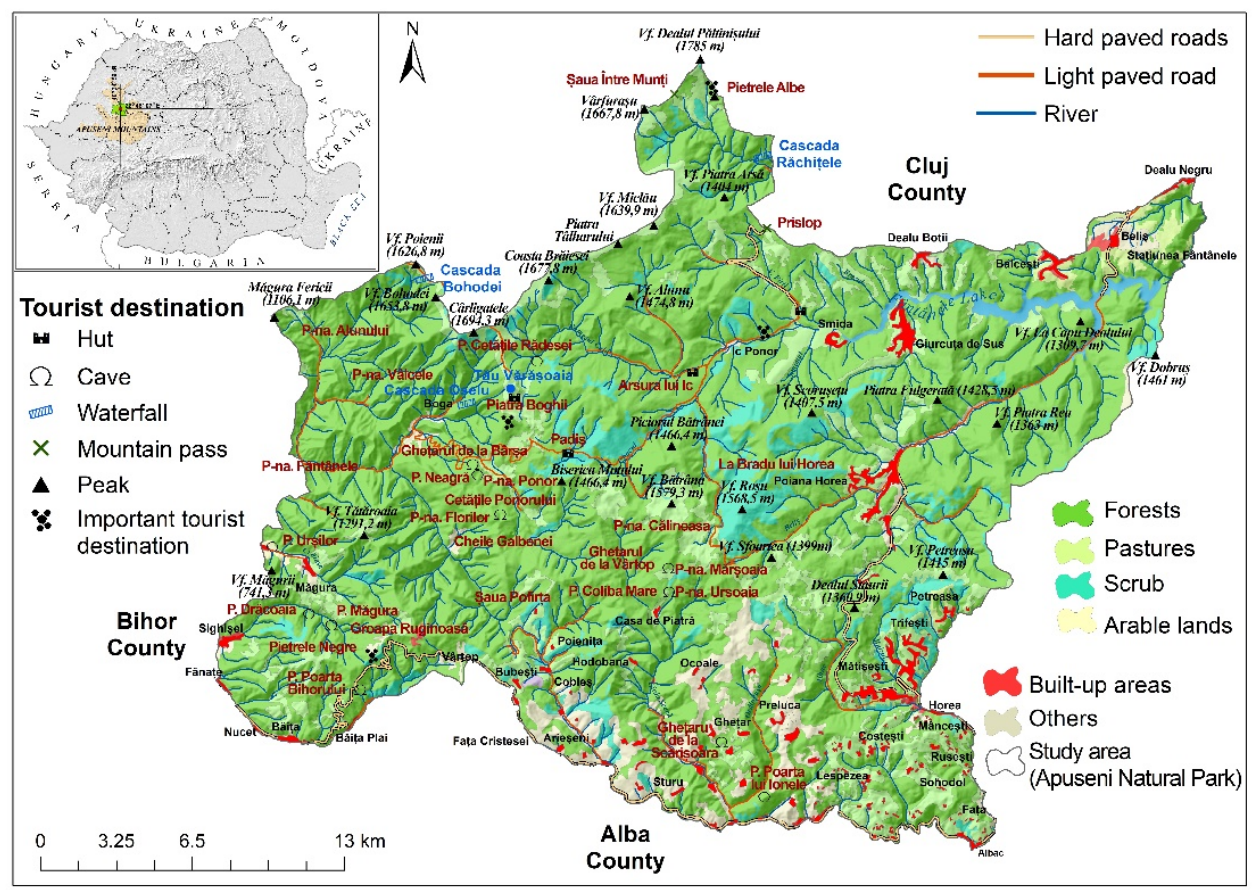

Figure 1. The Apuseni Natural Park area.

Source: Map processed in ArcView 10.5.1, using CLC 2018. Author: Roxana Cuculici, 2019

Table 1. Top sights with heritage value in the studied area

\begin{tabular}{ll}
\hline NATURAL TOURIST SIGHTS & SUPERLATIVES \\
\hline Fortress Ponorului Cave & the most spectacular karst site in Romania \\
\hline Scărișoara's Glacier Cave & the longest cave sheltering glaciers \\
\hline Valea Rea Cave & $\begin{array}{l}\text { the most decorated cave, with unique } \\
\text { crystallization, }>37 \text { minerals }\end{array}$ \\
\hline Altarului Stone & $\begin{array}{l}\text { the cave has the most beautiful cave formations } \\
\text { in Romania }\end{array}$ \\
\hline Pârâul Hodobanei Cave & the longest labyrinth cave in Romania \\
\hline Tăuz Cave & the deepest underwater cave \\
\hline Pit Cave & the deepest cave in Romania \\
\hline Glacier under Zugrăbești Cave & the cave sheltering the largest lake \\
\hline Ventilator Water Fall (82 m in Bad & the largest cascade in Romania, in the Bad \\
Valley Cave) & Valley Cave \\
\hline Coliboaia Cave, Sighiștelului Valley & it has wall paintings dating back > 30,000 years \\
\hline Ruginoasa Pit & a huge torrent in the shape of an amphitheater \\
\hline Scărișoara, Focul Viu (Padiș), Borțig, & caves sheltering perennial glaciers \\
Barsa (Padiș), Vârtop (Stone House) & \\
\hline Source: Bleahu et al.1967, Linc et al., 2011 &
\end{tabular}

Source: Bleahu et al.1967, Linc et al., 2011

The people residing in this area (the so-called motii) are one of the most representative mountain populations in Romania. They live especially in the villages lying around the cities of Câmpeni and Abrud, and so far they have preserved their traditions and customs, especially woodcarving (Abrudan \& 
Turnock, 2000). Gradually, the moți communities spread with their families, the name moți starting to be also used for the inhabitants of a larger area nearby the park (e.g. Crișul Alb superior valley, which crosses the Țara Zarandului, and to some communities belonging to Bihor, Hunedoara, Arad and Cluj counties) (Abrudan \& Turnock, 1998). Traditionally, however, the genuine moți are only the inhabitants of the villages located to the north and northwest of the Câmpeni city (the Alba County), namely Avram Iancu, Vidra de Jos, Vidra de Mijloc, Ponorel, Scărișoara, Albac, Horea, Neagra, Arieșeni etc (Surd, 1992).

Besides, the local communities (and especially the moți) have preserved their culture and traditions, continuing for instance, even at present, to employ traditional agricultural techniques.

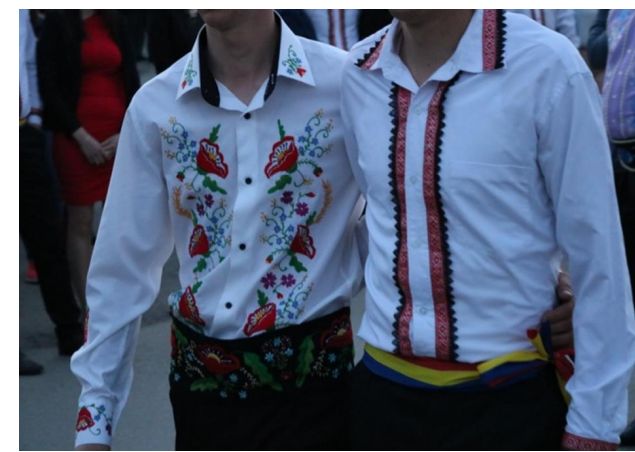

Photo 1. Traditional moți costumes Source: Laura Orbu, 2018

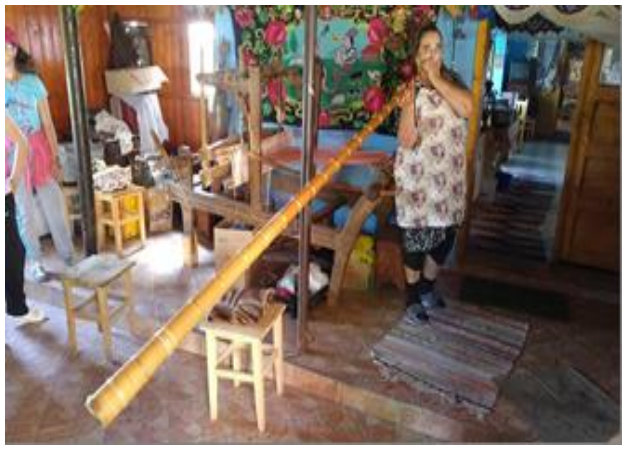

Photo 2. Bucium (traditional instrument) Source: Laura Orbu, 2018

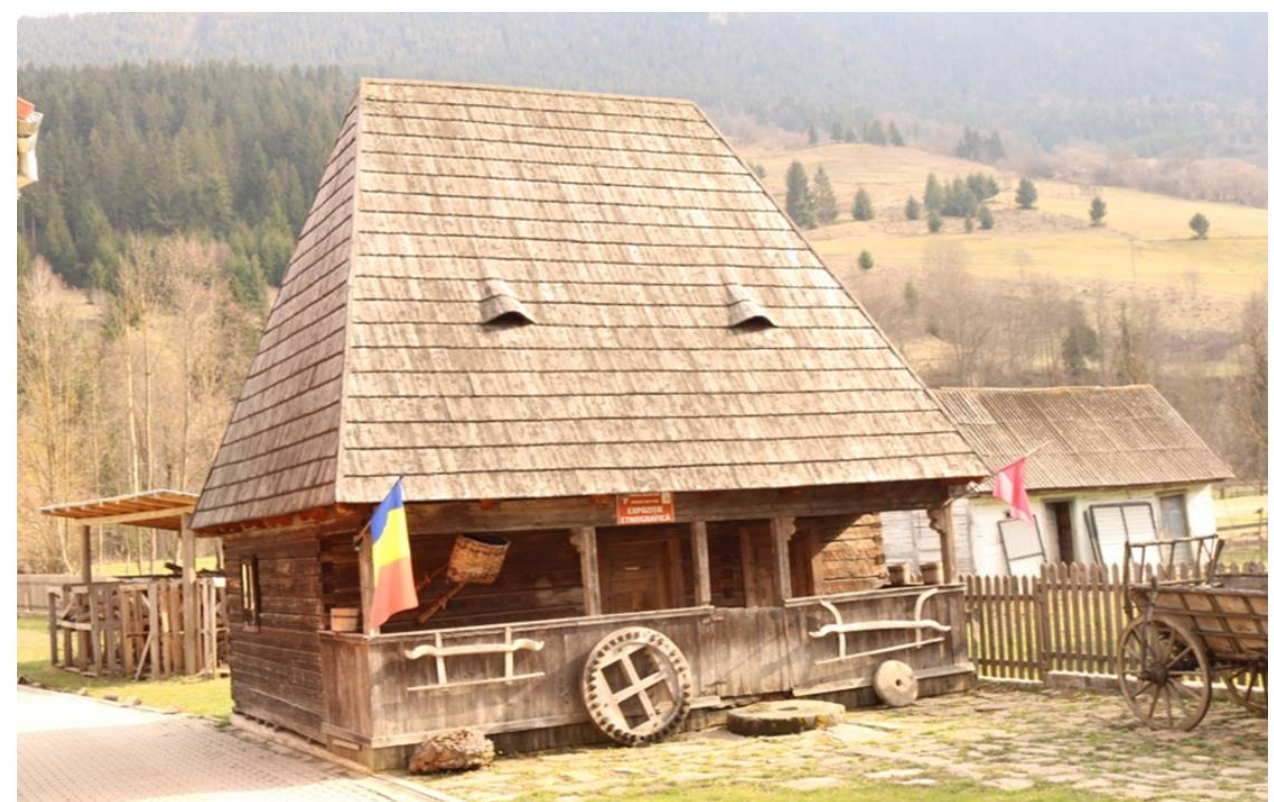

Photo 3. Traditional house in the Apuseni Mountains Source: Laura Orbu, 2018 


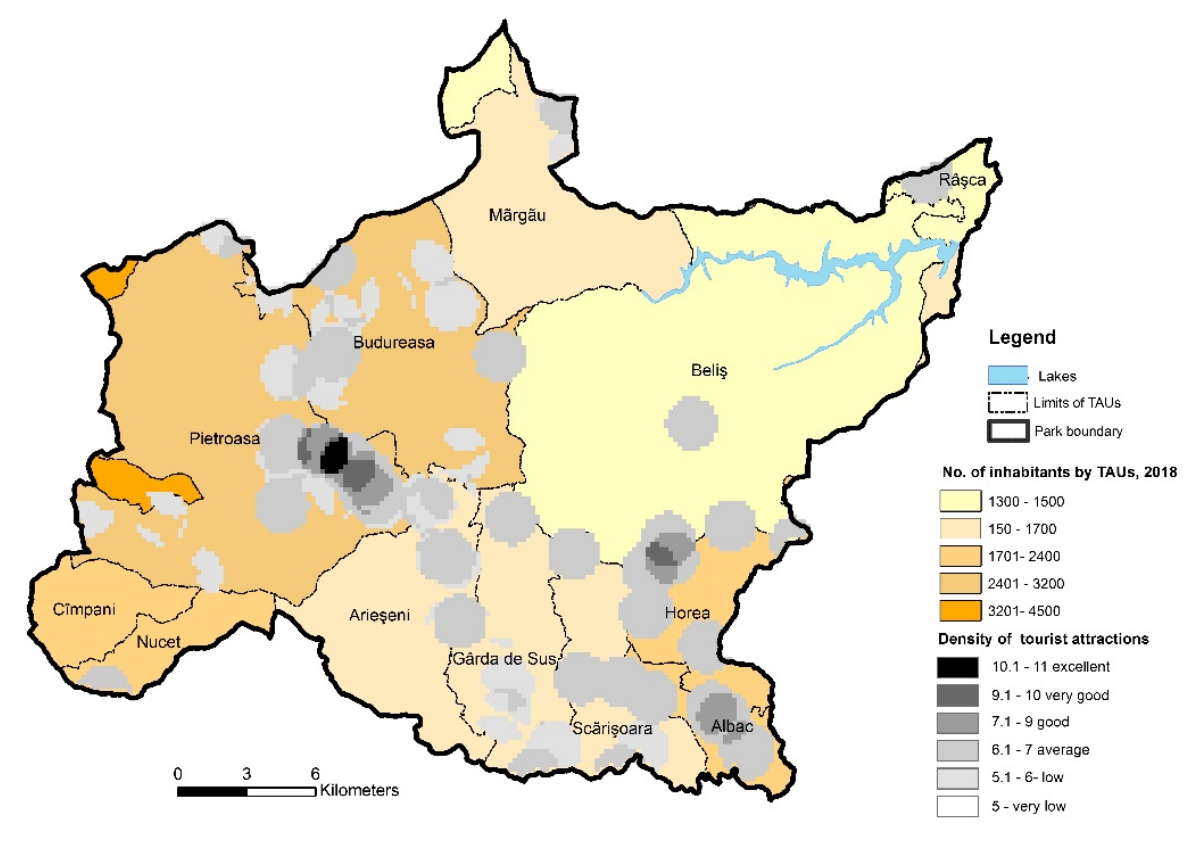

Figure 2. The concentration of specific tourist attractions in comparison with population size (2018)

Source: Data population processed after the NIS data in ArcGIS 10. 3.1.

All these elements explain why the Apuseni Mountains were designated "European destination of excellence" at EDEN 2009 contest. The main tourist attractions, as a part of attractiveness (Matei et al., 2019) estimated by their density in GIS (Spatial analyst tools) present a concentration on a northwest-southeast alignment; their density is the highest in the northern communes of the park belonging to the Bihor and Alba counties, while scattered values occur in the communes lying in the Cluj county. Overlapping this distribution with the populated areas has allowed the authors to ascertain that the alignment of these attractions mirrors the most populated areas (Figure 5). In the frame of a total capacity of accommodation of about 1,500-bed places, the area recorded almost 20,000 tourists (NIS, 2018). The tourist flows are heading towards Arieșeni, where a well-equipped ski slope is in operation. In the same location, the development of tourist amenities has influenced local business, which reflects the highest share of restaurants (25\%) and accommodation units (40\%) (Figure 3). The tourist infrastructure somewhat follows the concentration of attractions.

The territory's accessibility is facilitated by the nearby airports at Cluj Napoca and Oradea, by the national roads (DN/NR 75), which are linked to the European corridors (E60, E79), and by the railway (Oradea - Cluj Napoca). All these encourage people to visit the area. Inside the park, the accessibility is provided by several regional, county, or communal roads, which make the connection with the European and national roads. However, in the central part of the area, roads are very poorly maintained (Pietroasa - Padiș Plateau - Ponor - Răchițele). 


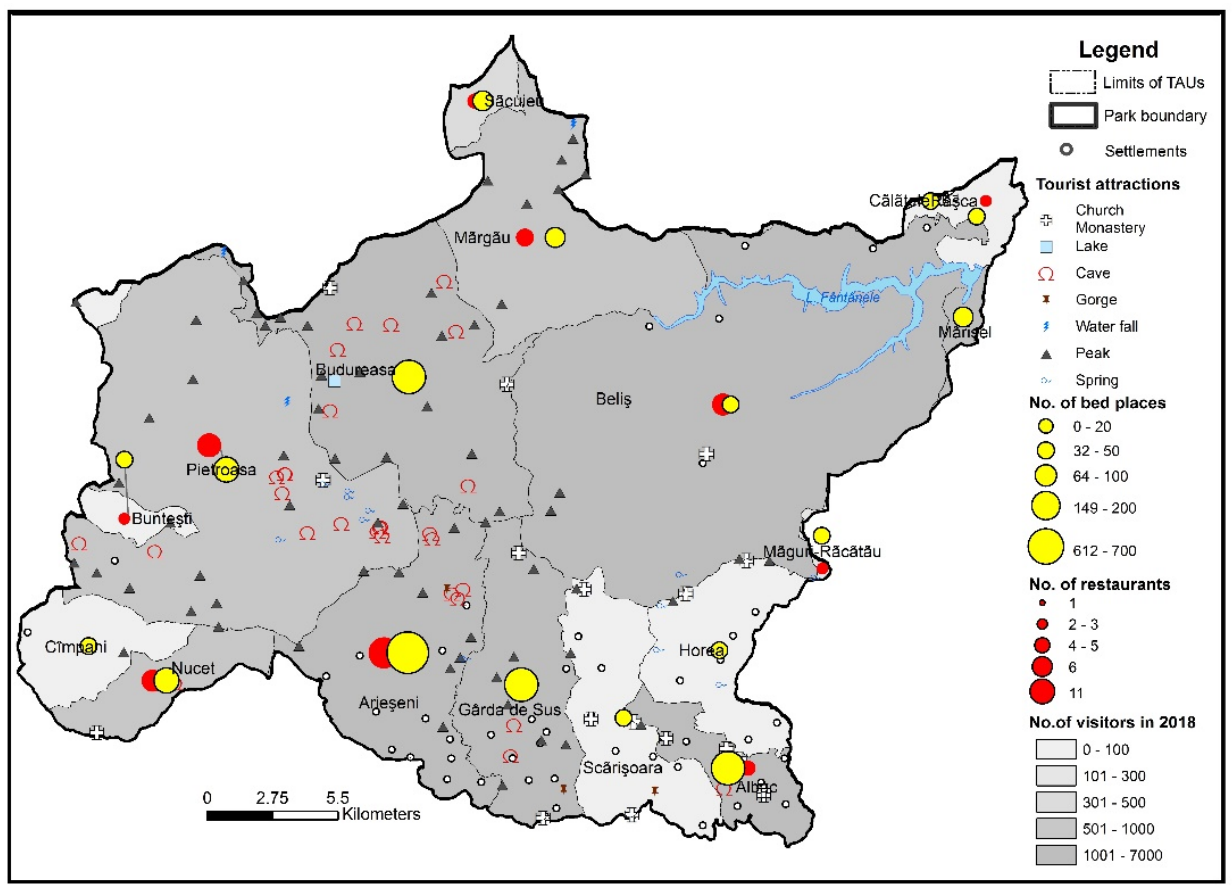

Figure 3. Tourist arrivals, accommodation capacity, food services and tourist attractions, in 2018

Source: Statistical data processed after the information provided by the NIS and the Ministry of Tourism, 2018.

An advantage of the area is that the main access points in the park are connected with European corridors: Sudrigiu - E79, starting from Deva or Oradea, Albac - DN75, which crosses the area on the east-west direction until it joins E79 road at Ștei, and Beliș (1R). As far as the settlements within the park are concerned, these have bus terminals allowing tourists who come without their vehicles to reach any attraction of the protected area. Within the park, there is no railway, but the large cities in the vicinity can be reached by rail.

\section{Results and Discussions}

Heritage advantages vs economic constraints in endogenous vs exogenous perception

The two endogenous and exogenous target groups of respondents $(60 \%)$ say that a natural park represents a protected area in which the role of human communities is important in preserving natural, cultural, ecological and biological values. They emphasised that the role of humans is most important in a natural park. The advantages seen by the two groups fundamentally differ. Thus, local communities found more items related to the social dimension (3), ranking at top of them "the rising their living standards" (76\%), "financial support for protection" (48\%), followed by the environmental dimension with two advantages: the protection of biodiversity (76\%) and a sustainable resource management (72\%). 
In the case of the economic dimension the increase of possibilities for local products to be capitalised is underlined. Even though many respondents do not have a clear picture of the internationalisation of the tourist image of the park, however, $40 \%$ believe that this benefit is very important (Table 2, column 3). Visitors are more focused on the benefits/advantages related to the environmental dimension (4), of which important to notice are "protection for natural sites" and "harmonisation of the man-nature relationship" (84\%).

These are in some degree in line with their purpose as tourist consumers, thinking that the environmental conservation in a destination will deliver high satisfaction in their experiences. They have the same high perception for the economic dimension, linking positive influence of the park management to the traditional activities, practices, culture of the local population (84\%), but less for the development of leisure activities (60\%). The issue of change in local life is much more homogenous in their view (Table 2). They see a significant asset in the fact that local communities may have access to a better life, a target also emphasised in the SDG 2030 of UN Agenda.

The survey results summarized in Table 3 structured a hierarchy of the responses regarding constraints due to the management of a natural park. For both groups, it is noted that life in a protected area of category V IUCN does not bring considerable economic constraints (Table 3-1). In contrast, economic development in such a specific legislative framework will certainly stimulate the growth of built-up surfaces (e.g. second residence homes, tourist infrastructure). Concerns about this issue are higher for visitors, based on their experiences from other destinations in the country and abroad and much more homogenous to the local population (Table 3-2). Both groups agreed that the environment would suffer degradation due to the tourist infrastructure, but a greater concern is expressed by visitors (68.5\%) than local inhabitants (40\%), (Table 3-3). It is quite unexpected that the survey revealed that visitors are more concerned about the probability of exposure to physical but also moral pollution, in the sense of the occurrence of acts of corruption or eviction of laws (Table 3-4). Conventional pollution underlined consists of waste dispersal by tourists or garbage disposals in back yard in some households. There is also a great fear of possible illegal deforestation episodes.

For the variable called "human pressure on the environment" (overcrowding effect), the two groups show a certain homogeneity, which denotes that they expect high pressures on the space generated by the flows of tourists, especially uncontrolled mass tourism (Table 3-5). There is a great fear related to the loss of traditions because the two cohorts of respondents have many answers evaluated with 5. The impact of cultural exchanges that usually take place between tourists and locals is viewed with more significant concern by visitors. The local community definitely knows their resilience, and they are more sceptical about the power of change and hence the loss of the heritage of local cultural and economic traditions (Table 3-6). 
Table 2. The endogenous and exogenous respondents' perception about the advantages in the National Park Apuseni Mountains coupled with the dimensions of sustainable development (1-very low; 5-very high)

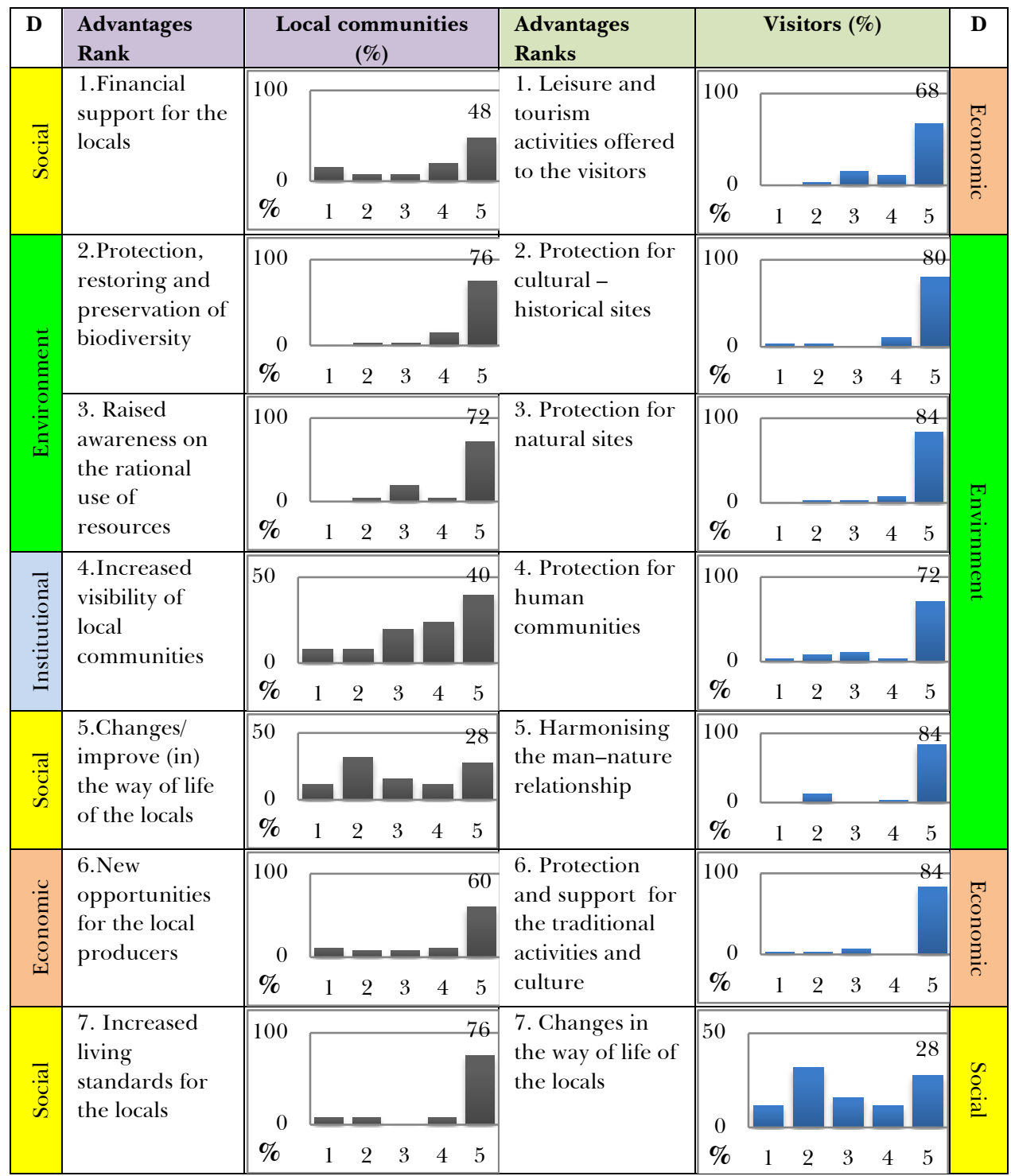

\section{Note: D-dimensions}

Related to the previous item and the perception about the question "changes in the way of life of the locals", a greater is noted among the visitors than among the locals. The last group has very balanced opinions (Table 3 - 7). In this context, the problem is not that the locals will live better, but that many cultural resources will disappear with them as well as the destination's ability to attract visitors. In our study area, as at national level, there is a strong migration of the young population to the European countries, for jobs, many of them ending with the definitive removal of their residence from Romania. Thus, traditions are much more likely to be lost. 
Table 3. The endogenous and exogenous respondents' perception about constraints in study area coupled with sustainable development' dimensions (1-very low; 5-very high)

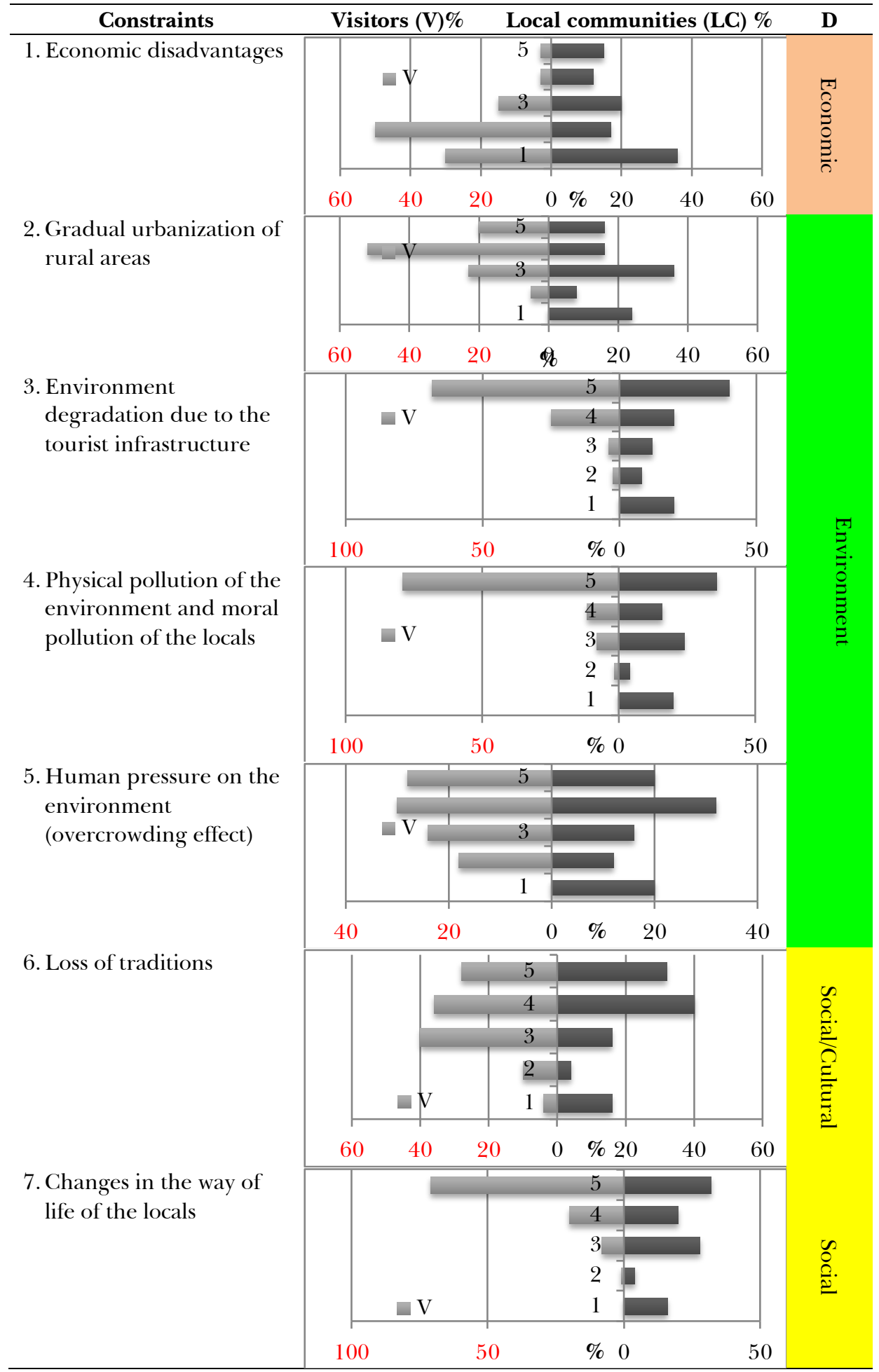




\section{Solutions to mitigating constraints and reinforce benefits}

By collecting and analysing the ideas provided in the open questions of the survey by the representatives of the two groups, it was observed that those with specific mountaineering occupations brought valuable ideas. Tourist attractions still need more and more nuanced planning, with information centres, visitors centre, and access in or towards the protected sites. These request investments in rehabilitating the county and local roads, especially in the Padis area and the northern and eastern parts of the park; marking the paths leading to the most important tourist sights, creating gate of access from the east for tourists coming from all directions. Most of them demand to modernise the tourist infrastructure and construct them on ecological principles, minimising the negative impacts on the environment. It is fundamentally important to find solutions to increase tourists' satisfaction and loyalty which translates into repeated visits. Such solutions include improving the visibility of the park by its better promoting as a tourism destination online, which needs that the park's web-site to be modernized and updated. The recreational activities should be diversified through extensive national and international events.

For local communities, all these suggestions mean economic gains as workforce in the activities carried out within the park and the improvement of their life. It is assumed that external migration of the young population that occurred during the period 1990-2015 will be diminished. Even if Romanians have gained the experience regarding the protection of the environment, there is still the need of complying with legislation, granting financial compensations, raising the awareness about the harmful effects of the intensive exploitation of environmental resources. It is also an urgent necessity to protect the material and non-material heritage of the local communities, as an integral part of the environment and capitalising the local products, preserving the identity of the territory from contamination with outside elements and responsibly managing the local resources. Nothing will be possible without fostering the collaboration among the authorities and the local people (Matei et al., 2013).

\section{Conclusions}

The Apuseni Mountains Natural Park is a protected area and a tourist destination at the same time. In this respect, the protection of natural and human capital should balance economic recovery. Being a protected area, it becomes a subject of conservation legislation and rules, and as a tourist destination, it can only develop if it is aligned with the directions of sustainable tourism development. This space, divided among the use of local communities, tourists, investors, local authorities need to consult all these groups' representatives in order to make the best decisions for maximising advantages to obtain benefits and reduce impacts and constraints. The heritage advantages are attributed more to the social benefits by the locals, compared to the tourists who give much strength to the 
environment, starting from the tourist infrastructure, balancing, and the harmonising the relations with the environment, up to raising the standard of living for the population.

Regarding the constraints, it is observed, on the one hand, that tourists are more worried about the aspects of the slightly chaotic economic development that will lead to losses of the natural and anthropic heritage compared to the local population, which is more optimistic. As connoisseurs of the region, the solutions suggested by interviewers focused on improving management, re-planning access to the park, inside it, towards the attractions, aligning the tourist services to the requirements of sustainable development, focused on environmentally friendly acquisitions, programs on maintaining and publicizing the cultural heritage, and increasing the visibility of the region through digital tech means. It is generally argued that better management of the park would bring other benefits, mitigating the external migration of the young population and negative dynamic of the population.

\section{Acknowledgements}

Authors thanks all respondents involved in research. All the authors have equal contributions to this article.

\section{References}

Abrudan I.V. and Turnock D., (1998), "A rural development strategy for the Apuseni Mountains, Romania", GeoJournal, vol. 46, no. 3, p. 319-336.

Abrudan, I.V. and Turnock, D. (2000), "Romania's Apuseni Mountains: Safeguarding a cultural heritage", GeoJournal, no. 50, vol. 2/3, p. 285-304.

Almeida-García, F., Peláez-Fernández, M.Á., Balbuena-Vázquez, A. and CortésMacias, R. (2016), "Residents' perceptions of tourism development in Benalmádena (Spain)", Tourism Management, vol. 54, p. 259-274.

Angelevska - Najdeska, K. and Rakicevik, G. (2012), "Planning of sustainable tourism development", Procedia-Social and Behavioral Sciences, vol. 44, p. 210-220.

Ap, J. (1992), "Residents' perceptions on tourism impacts", Annals of Tourism Research, vol. 19, no. 4, p. 665-690.

Bleahu, M., Bordea, S. and Borza, Al. (1963), Munții Apuseni, ONT Publishing House.

Budeanu, A., Miller, G., Moscardo, G. and Ooi, C.S. (2016), "Sustainable tourism, progress, challenges and opportunities: an introduction", Journal of Cleaner Production, vol. 111, p. 285-294.

D’ Mello, C., Chang, L.Ch., Pillai, S.K.B., Kamat, K., Zimmermann, F.M. and Weiermair, K., (2016), "Comparison of multi-stakeholder perception of tourism sustainability in Goa", International Journal of Hospitality \& Tourism Systems, vol. 9, p. 1-13.

Domínguez - Gómez, J.A. and González-Gómez, T. (2017), "Analysing stakeholders' perceptions of golf-course-based tourism: A proposal for 
developing sustainable tourism projects", Tourism Management, vol. 63, p. 135143.

Foris, D., 2014, "Study Regarding a New Dimension of Tourism Phenomenon The Political - Administrative Dimension", Procedia - Social and Behavioral Sciences, vol. 143, p. 1078-1082.

Hardy, A. and Pearson, L.J. (2017), "Examining stakeholder group specificity: An innovative sustainable tourism approach", Journal of Destination Marketing $\mathcal{E}^{\circ}$ Management, vol. 8, p. 247-258.

Jarvie, M.E. 1987, Brundtland Report, World Commission on Environment and Development, viewed 5 May 2018, https://cutt.ly/PePb4uA.

Linc, R., Nistor, S. and Turnock, D. (2011), "Aspects regarding the environmental impact of tourism activities in the Apuseni National Park. Romania", Analele Universității din Oradea - Seria Geografie, vol. 2, p. 340-353.

Lyon, A., Hunter-Jones, P. and Warnaby, G. (2017), "Are we any closer to sustainable development? Listening to active stakeholder discourses of tourism development in the waterberg biosphere reserve, South Africa", Tourism Management, vol. 61, p. 234-247.

Main, D., 2018, In Transylvania, A Fierce Battle Over Gold and Roman History, National Geographic, viewed 20 August 2019, https://cutt.ly/xePnwmo.

Matei, E. (2016), Turism și dezvoltare durabilă, Bucharest, Universitară Publishing House.

Matei, E., Dumitrache, L., Manea, G., Vijulie, I., Tîrlă, L. and Matei, D. (2013), Urban sustainable development of the Romanian small towns in the local communities and authorities' perception, SGEM Conference proceedings, vol. 3, Bulgaria.

Matei, E., Dumitrache, L., Nae, M., Vijulie, I. and Onetiu, A. (2011), Evaluating sustainability of urban development of the small towns in Romania, SGEM Conference proceedings, vol. 3, Bulgaria.

Matei, E., Stăncioiu, F.A., Vijulie, I., Manea, G, and Cuculici, R. (2019), "Attractiveness and Competitiveness in the Romanian Carpathian Mountains Destinations: A study of Perception of Generation Y", Journal of Environmental and Tourism Analyses, vol. 7, no. 1, p. 5-18.

NA, 2009, Parcul Natural Apuseni, premiat de Comisia Europeana, viewed 12 May 2018, https://cutt.ly/AePbKdS.

Surd, V., (1992), "Sistemele de asezari din Muntii Apuseni", Geographia, Studia Universitatis Babeș-Bolyai, vol. 1-2, p. 9-20.

UNEP, (1972), Declaration of the United Nations Conference on the Human Environment, United Nations Environment Programme.

UNEP, (1992), United Nations Conference on Environment E Development, Rio de Janerio, Brazil, 3 - 14 June, Agenda 21, viewed 18 August 2019, https://cutt.ly/JePnppl.

UN-HABITAT, 2002, World Summit on Sustainable Development, Johannesburg, viewed 18 August 2019, https://cutt.ly/SePnF6B.

Wu, K.J., Liao, C.J., Tseng, M. and Chiu, K.K.S. (2016), "Multi-attribute approach to sustainable supply chain management under uncertainty", Industrial Management and Data Systems, vol. 116, no. 4, p. 777-800. 